\title{
The pigeonhole principle, two centuries before Dirichlet
}

\author{
Benoît Rittaud * $\quad$ Albrecht HeEffer ${ }^{\dagger}$
}

February 25, 2013

\section{The pigeonhole principle}

The pigeonhole principle states that when objects are placed into boxes and when there are more objects than boxes, then there will be at least one box containing at least two objects. The most striking utilization of such a simple principle is probably Dirichlet's theorem on diophantine approximation: for any real number $\theta$ and any positive integer $Q$, there exists integers $p$ and $q$ with $0<q \leq Q$ such that

$$
\left|\theta-\frac{p}{q}\right|<\frac{1}{q Q}
$$

The name of Dirichlet is commonly associated to the pigeonhole principle, since it is widely believed that he was the first to state it. In the writings of Dirichlet, the application of the principle is to be found in 1842 in [7] and [5] (both reproduced in [8], see p. 579-580 and p. 633-638) and, later, in [6]. It seems that no one knows any precise prior reference, even if the year 1834 is frequently mentioned as the year of the discovery (for some details on later references, see [15]). In [7] and [5], the pigeonhole principle is used to prove complex and multidimensional versions of Equation 1. In the second reference, of 1863 (hence published four years after Dirichlet's death), it is used to provide a proof of the existence of infinitely many integers $x$ and $y$ such that $x^{2}-y^{2} D<1+2 \sqrt{D}$ (for $D$ integer and not a perfect square) which does not rely on continued f ractions. In these publications Dirichlet does not assign any name to the principle, nor does he pretend that this principle is new. In a later work he calls it the "Schubfachprinzip".

Anyway, it appears that Dirichlet was not the first to make use of the principle that bears his name. The pigeonhole principle appeared no less than two centuries before him.

*Université Paris-13, Sorbonne Paris Cité, Laboratoire Analyse, Géométrie et Applications, CNRS, UMR 7539, F-93430 Villetaneuse, France. rittaud@math.univ-paris13.fr

${ }^{\dagger}$ Ghent University, Center for History of Science. LW01 Blandijnberg 2, B-9000 Ghent, Belgium. albrecht.heeffer@ugent.be 


\section{Jesuit mathematics education}

In SelectcPropositiones, a book written in latin in 1622 by the French Jesuit Jean Leurechon, the pigeonhole principle is indirectly mentioned in a single short sentence, given without any further elaboration ([13], p. 2): "It is necessary that two men have the same number of hairs, gold, and others." ${ }^{1}$ The famous Marin Mersenne copied several propositions on arithmetic and music from Leurechon, including this mathematical principle in an early work of $1625,{ }^{2}$ acknowledging the "excellent conclusions obtained from arithmetics" by the mathematicians from Pont-à-Mousson.

Pont-à-Mousson, a French town in the Lorraine region was home to a flourishing Jesuit university. With the official guidelines from Rome, the Ratio Studiorum, all Jesuit universities were required to establish a chair of mathematics. The university of Pont-à-Mousson was one of the first to do so. From 1611 onwards the chair of mathematics was assigned to a succession of young jesuits who often were still in their theology studies. They were replaced as soon as they acquired some experience in teaching moving up from mathematics to philosophy and hence theology. The best known mathematician was Jacques de Billy who held the chair from 1629 to 1630, while studying theology.

Jean Leurechon was a factor of stability at Pont-à-Mousson, teaching mathematics on and off between 1614 and 1629. His short SelectcePropositiones from 1622 was a collection of propositions in mixed mathematics that were used for teaching. The booklet is one of the earliest witness accounts of the new mathematics curriculum at Jesuit colleges. Teaching was organised in lectures (lectiones), rehearsals (repetitiones) and discussions (disputationes). The disputationes were held on a weekly, monthly and publicly on a yearly basis, attracting an audience from the nobility and the gentry. The public disputationes on mathematics aspired to render arithmetic and geometry more tangible by applying it to well known phenomena or to device material tools for making it imaginative for a larger audience. For example: summations of geometric progressions were applied to "prodigious progression and multiplication of creatures, plants, fruits, numbers, gold, silver, \&c. when they art always augmented by certain proportion", and thus establishing the very first mathematical modeling of the evolution of populations. Conic sections were discussed by cutting geometrical figures in cardboard in which inflexible bodies such as cylinders, pyramids and spheres were passed.

It is now established that an immensely popular work published at Pontà-Mousson in 1624 resulted from these disputationes [12]. Entitled Récréation mathematicque [1], this French work is commonly attributed to Jean Leurechon, but there are good reasons to believe that this attribution is wrong (see [11]). More than seventy editions and translations were published during the seventeenth century. (The first English translation appeared in 1633 [2].) The pigeonhole principle appears at the end of the book (just after some elementary

\footnotetext{
1 "Necesse est, duos hominum, habere totidem numero pilos, aureos, 65 similia."

2 [14], pp. 803-4, "il est nécessaire que deux hommes aient autant de cheveux, d'escus, \& d'autres choses l'un comme l'autre".
} 
remarks inspired by Archimedes' Sand Reckoner about the number of grains of sand that could fill the universe). Unfortunately, this remarkable part of the book does not appear in the English edition.

That it is absolutely necessary that two men have as many hairs or pistoles as the other.

It is certain that there are more men in the world than the number of hairs or pistoles of the most haired or most wealthy man: and since we do not know exactly how many men there are, neither the number of the most haired of all, taking finite numbers for others equally finite, let us assume that there are 100 men and that the most haired of them has only 99 hairs. I could as well take 2 or 3 hundreds millions men and hairs, but for the sake of simplicity I choose smaller numbers, which does not affect the demonstration. Hence, since there are more men than hairs in any of them, let us consider 99 men and say: either these 99 all have a different number of hairs, or there are some which are equal. If you say that some are equal, then my proposition is true. If you say that they are not equal, then it is necessary that someone has only one hair, another two, another $3,4,5$, and so for the others until the $99^{\text {th }}$. And how many will the hundredth have? As posed, he cann ot have more than 99 ; it is therefore necessary that he has some number smaller than 100 , so necessarily, two men have have as many hairs as the other.

In the same way, we could conclude that it is necessary that two birds have as many feathers, two fishes as many scales, two trees as many leaves, blossoms or fruits, and maybe as many leaves, blossoms and fruits at the same time, provided that the number of trees is large enough. Also, we could wager, that an assembly of hundred persons in which no one has more than ninety nine pistoles, necessarily, two of them have as many as the other.

It might as well be said that a book, provided that its number of pages is larger than the number of words contained in any page, it is necessary that two pages can be found with the same number of words, etc.

Récréation mathematique (1624), p. 131-132.

\section{$3 \quad$ The legacy}

It is quite astonishing that the example of men with the same number of hairs is still a very common illustration of the principle (see for example [4] p. 3 where the case of New York City is considered, or [10] with the inhabitants of Madrid, etc.). Not only the origin of the example of number of hairs seems to be forgotten but also the origin of the pigeonhole principle itself. It strongly suggests that the SelectcePropositions - not necessarily being the origin of the 
very idea - has left a strong legacy. Indeed, the problem of men with the same number of hairs appeared in 1737, in a totally different context, in a French book by Charles-Irénée Castel de Saint-Pierre, which is in no way related to mathematics. This book contains a (highly misogynous) depiction of Madame de Longueville, as a woman unable to understand even the most basic science. Castel de Saint-Pierre reports an anecdote on her, related by a friend of him named $\mathrm{Nicole}^{3}$ :

(...) one day, I said to her that I could wager and demonstrate that there were in Paris, at least two inhabitants who had the same number of hairs, although I could not point out who these two men were. She told me, I could never be sure of it until I had counted the hairs of these two men. Here is my demonstration, I said: -I take it for granted that the head which is most amply supplied with hairs has no more than 200,000 and the head which is least so has but one hair. Now, if you suppose that 200,000 heads have each a different number of hairs, it necessarily follows that they have each one of the numbers of hairs which form the series from 1 to 200,000 (...) If I add a single inhabitant (...), this number of hairs, whatever it may be, will be contained in the series from 1 to $200,000(\ldots)^{4}$

In the middle of the nineteenth century, the famous French writer CharlesAugustin Sainte-Beuve quoted extensively this passage in several publications ([16], [17], [18]), at the very same time Dirichlet made use of the principle in a purely mathematical context.

So, do we have to replace the old "Dirichlet's pigeonhole principle" by a "Leurechon's pigeonhole principle"? We do not know for sure if Leurechon was really the first to publish the result. David Singmaster's comprehensive Sources in Recreational Mathematics [19] and our survey of Italian abbaco manuscripts revealed no earlier instances. However, the practical context in which the principle is presented and the Euclidean-style proof provided by Leurechon fits very well within the mathematics education program by the Jesuits. We would say that Leurechon deserves some more credit for this and many other discoveries which we find in the Mathematicall Recreations.

\section{References}

[1] [Jean APPIER HANZELET], Récréation mathematicque composee de plusieurs problemes plaisants et facetieux, Jean Appier Hanzelet (1624).

[2] [Jean Appier Hanzelet], Mathematicall Recreations, T. Cotes (1633).

[3] Charles-Irénée Castel de Saint-Pierre, Ouvrajes de morale et de politique, Beman (1737).

\footnotetext{
3 [3], p. 88-89. Pierre Nicole was together with the mathematician Antoine Arnauld author of the influential treatise on rational thinking, La Logique de Port-Royal (1662).

${ }^{4}$ This English translation is extracted from [9].
} 
[4] Morris Cohen \& Ernest Nagel, An Introduction to Logic, Hackett Publishing (1993).

[5] Peter Gustav Lejeune DiRICHLET, "Verallgemeinerung eines Satzes aus der Lehre von den Kettenbrüchen nebst einigen Anwendungen auf die Theorie des Zahlen", Bericht über die Verhandlungen der Königl. Preuss. Akademie der Wissenschaften (1842), p. 93-95.

[6] Peter Gustav Lejeune DiRIChlet, Vorlesungen über Zahlentheorie, F. Vieweg (1863), p. 405-406.

[7] Peter Gustav Lejeune DiRichlet, "Recherches sur les formes quadratiques à coefficients et à indéterminées complexes", Journal für die reine und angewandte Mathematik, 24 (1842), p. 291-371.

[8] Peter Gustav Lejeune Dirichlet, Werke, vol. 1, Reimer (1889).

[9] George Eliot, Silly Novels by Lady Novelists, Penguin UK (2010).

[10] Miguel de GuZmán, Aventuras Matemáticas, Pirámide (1995).

[11] Albrecht HeEffer, "Récréations Mathématiques (1624) A Study on its Authorship, Sources and Influence", Gibeciere 1, no 2 (2006), p. 77-167.

[12] Albrecht HEEFfER, "Wonder to those who are ignorant in the cause". A modern edition of Récréation Mathématique (1624) based on its English translation, with an introduction and notes, a glossary and commentaries, Springer (forthcoming).

[13] [Jean Leurechon], SelectePropositiones in Tota Sparsim Mathematica Pulcherrimc, Gasparem Bernardum (1622).

[14] Marin Mersenne, La Vérité des sciences, Toussainct du Bray (1625).

[15] Jeff Miller, "Earliest Known Uses of Some of the Words of Mathematics (P)", http://jeff560.tripod.com/p.html (last revision Aug. 4, 2011).

[16] Charles-Augustin Sainte-Beuve, "Madame de Longueville", Revue des deux mondes 3, 359-377 (1840).

[17] Charles-Augustin Sainte-Beuve, La Bruyère et la Rochefoucauld. Mme de La Fayette et Mme de Longueville, Fournier (1842).

[18] Charles-Augustin Sainte-Beuve, Portraits de femmes, Didier (1844).

[19] David Singmaster, Sources in Recreational Mathematics, Eighth Preliminary edition (unpublished copy by the author). 